\title{
Effect of food products on endogenous generation of $N$-nitrosamines in rats
}

\author{
BY V. K. ATANASOVA-GORANOVA ${ }^{1}$, P. I. DIMOVA ${ }^{2}$ \\ AND G. T. PEVICHAROVA ${ }^{3}$ \\ ${ }^{1}$ Department of Hygiene and Ecological Medicine and ${ }^{2}$ Department of Histology and Embryology, \\ Higher Medical Institute, Plovdiv, Bulgaria \\ ${ }^{3}$ Department of Vegetable Quality, 'Maritsa' Vegetable Crops Research Insititute, Plovdiv, Bulgaria
}

(Received 21 September 1995 - Revised 2 January 1997 - Accepted 7 January 1997)

\begin{abstract}
An experiment was conducted to study the efficacy of two tomato pastes and aronia nectar (fruit juice + pulp from the black chokeberry, Aronia melanocarpa Elliot) as inhibitors of nitrosamine production in cancer prophylaxis programmes. White male rats of the Wistar strain were employed in an acute trial. Aminopyrin + sodium nitrite (APSN) were used as precursors for generation of endogenous nitrosamine. The animals were allocated to different dietary groups and fed by intubation with APSN or APSN + food products. Introduction of tomato paste (TP), high- $\beta$ carotene tomato paste (HCTP) and aronia nectar (AN) as inhibitors of $N$-nitrosamine formation exerted a positive effect on blood and liver variables which was demonstrated by decreased concentrations of glutamic-oxaloacetic transaminase $(E C$ 2.6.1.1), glutamic-pyruvic transaminase (EC 2.6.1.2) and uric acid in serum and lipid content in hepatocytes. Animals treated with APSN developed dystrophic changes in liver such as centrolobular necrosis, intense exangia, and enlarged cells with two, often large, pyknotic nuclei, while the structure of livers of rats fed with TP, HCTP or AN was well protected and almost normal. TP had a particularly beneficial effect on serum total protein and albumin concentrations as had $A N$ on the urea value. The inhibitory effect of the food products used is explained by their chemical nature including $\mathrm{pH}$, ascorbic index (ascorbate : nitrate), lycopene and $\beta$-carotene contents.
\end{abstract}

Cancer prophylaxis: Nitrosamines: Tomato paste: Aronia nectar

Among various cancer prophylactic measures an important place is taken by inhibitors of nitrosation which generates the carcinogenic $N$-nitrosamines (Mitrov \& Chernozemski, 1985; Boyadjiev \& Markova, 1987; Lathia et al. 1988; Tannenbaum et al. 1991).

It has been proved that, in the stomach of animals and man, nitrosamines may be synthesized from non-carcinogenic precursors, i.e. nitrites and amines (Holmes, 1971; Rubenchick, 1977; Zhukova et al. 1990; Shahidi \& Pegg, 1993). The carcinogenic nitrosocompounds (NC) are formed mostly from secondary amines and amides. Nitrosation agents appear to be either nitrites or nitrates as the latter can be reduced endogenously to nitrites. Until now the inhibitory effect of compounds such as vitamins $\mathrm{C}, \mathrm{E}$, and $\mathrm{A}$, thiamin, riboflavin, niacin and tannins has been studied in detail and it has been shown that in their presence the nitrite anion is not able to react with secondary amines (Rubenchick, 1979; Tannenbaum, 1989; Zhukova et al. 1989; Mergens, 1992). The nitrosation process may be inhibited not only by isolated chemical compounds but also by the foodstuff which contains these inhibitors (Rubenchick et al. 1985). The object of the present experiment 
was to study the inhibitory effects of tomato paste (TP), high- $\beta$-carotene tomato paste (HCTP) and aronia nectar (AN) on endogenously generated nitrosamines in rats under acute experimental conditions.

\section{MATERIALS AND METHODS}

\section{Food products}

TP and HCTP were produced in the 'Maritsa' Vegetable Crops Research Institute, Plovdiv. Both were processed according to Bulgarian State Standard no. 508-85 (Council of Ministers, 1985). Red and high- $\beta$-carotene tomato varieties bred in the same institute were used as raw materials. Black chokeberry (Aronia melanocarpa Elliot) nectar (AN) was prepared according to Bulgarian State Standard no. 5162-81 (Council of Ministers, 1981) and the technological instructions of the Food Processing Industry (National AgroIndustrial Union, 1985). As defined by this standard, the fruit nectar is the fruit juice + pulp.

The chemical composition of these three products is presented in Table 1. The ascorbic index (AI) denotes the ratio ascorbic acid: nitrate content in the food product.

\section{Animals}

An acute experiment similar to those described by Kamm et al. (1975) was performed. White male rats of the Wistar strain with average weight about $200 \mathrm{~g}$ were randomly allocated to five dietary groups of ten animals each: group 1, control; group 2, aminopyrin + sodium nitrite (APSN); group 3, APSN + TP; group 4, APSN + HCTP; group 5, APSN + AN.

\section{Operative procedure}

On three consecutive days the animals were fed by intubation as follows: group 1, distilled water, $1 \mathrm{ml} / 100 \mathrm{~g}$ body weight $(\mathrm{BW})$; group $2, N$-nitrosamine precursors $(12.5 \mathrm{mg}$ aminopyrin $+11 \mathrm{mg}$ sodium nitrite (APSN) per $\mathrm{ml}$ water), $1 \mathrm{ml} / 100 \mathrm{~g} \mathrm{BW}$. Groups 3, 4 and 5 were given the same volume of APSN plus $1 \mathrm{ml} / 100 \mathrm{~g} \mathrm{BW}$ of TP, HCTP or AN respectively.

The trial was conducted at $21^{\circ}, 40-60 \%$ relative humidity with a $12 \mathrm{~h}$ light-dark cycle. The rats were killed by cervical dislocation on the 4 th day, $24 \mathrm{~h}$ after the last intubation.

\section{Tissue preparation}

Blood was collected from cervical blood vessels. A portion of it was immediately centrifuged and frozen at $-20^{\circ}$.

The serum was studied by Kone Dynamic apparatus (Kone Instruments Oy, Espoo, Finland) on the next day to determine total protein, albumin, non-protein $\mathrm{N}$ compounds (urea, creatinine, uric acid), and the enzymes glutamic-pyruvic transaminase (EC 2.6.1.2; GPT) and glutamic-oxaloacetic transaminase (EC 2.6.1.1; GOT). They were determined by means of the colorimetric methods of the Technicon RA-1000 ${ }^{\mathrm{TM}}$ system (Technicon Instruments Corporation, 1985). 


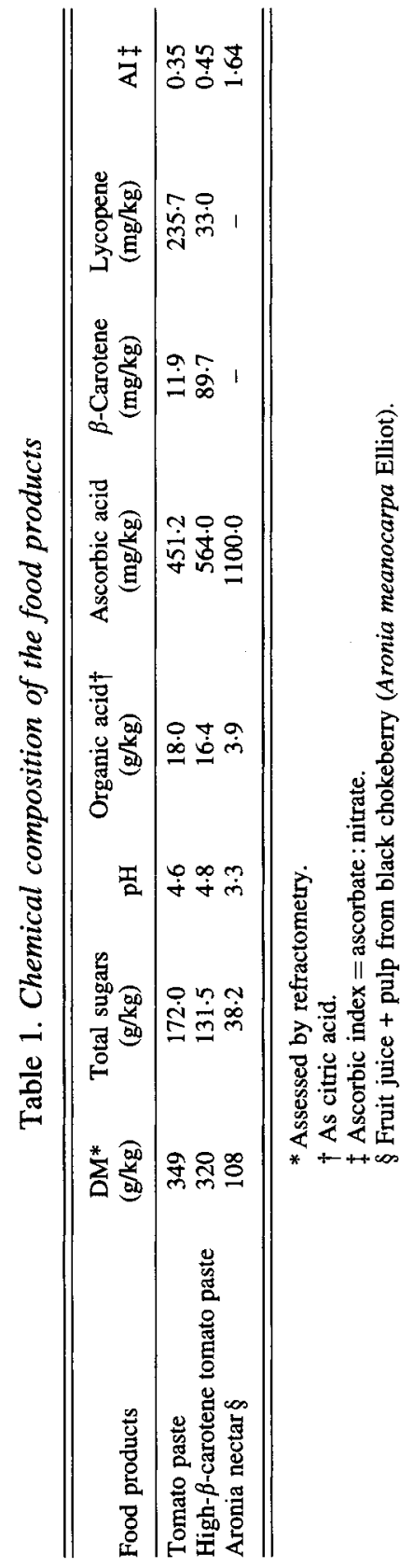


Another portion of the blood was used for analysis of haematological values: haemoglobin, erythrocytes, leucocytes, differential leucocyte count and erythrocyte sedimentation rate assessed by the Panchenko method (Todorov, 1962).

The liver was removed immediately and samples were taken for histopathological and histochemical examination. Paraffin specimens were prepared, which, after staining with haematoxylin-eosin, were studied by light microscopy. A test for total lipids was performed on cryostatic segments, 5-6 $\mu \mathrm{m}$ thick, by staining with Sudan III-H.

\section{Statistical analysis}

The data were evaluated by coefficient of variability and Duncan's multiple-range test.

\section{RESULTS}

\section{Effect of food products on some serum and haematological variables}

The inhibitory effect of the food products on some serum variables in rats is shown in Table 2. Groups 3 and 4 had significantly lower serum total protein and albumin concentrations in comparison with groups 1,2 and 5 .

The variables most indicative of liver damage are GOT and GPT. Substantial differences were found between group 2 , in which values were very high, and the other four groups.

Non-protein $\mathrm{N}$ compounds showed a different pattern in each group. AN, the diet with highest ascorbic acid content, was the only treatment which reduced the urea concentration. There were no differences among groups in serum creatinine content. Diets including TP, HCTP and AN led to lower serum levels of uric acid than in controls whilst APSN alone increased uric acid. The inhibitory effects of food products on the haematological indices are shown in Table 3. Haemoglobin was not affected by APSN but in group 4 (given HCTP) a value significantly below the control was obtained. The value for erythrocytes in the AN group was very similar to that in the control group while both groups receiving tomato paste had lower erythrocyte levels. The leucocyte count of the AN group was also close to that of the control. No significant differences were found among the five groups in erythrocyte sedimentation rate (Table 3 ) nor in differential blood count (Table 4).

\section{Effect of food products on liver structure and quantity of lipids in hepatocytes}

The histological examination of liver samples showed substantial differences in structure and lipid content in animals given APSN only (Fig. 1(c) and (d)) and those given APSN + TP or AN (Fig. 1(e) and (f)).

Animals treated only with APSN (group 2) developed dystrophic changes in the liver (compare Fig. 1(a) and (c)) while those treated also with TP or AN (groups 3,4 and 5) had a well-preserved liver structure (Fig. 1(e)).

The results from histochemical analysis showed that total lipid content in hepatocytes of group 2 animals was greatly increased (suggesting fatty degeneration; compare Fig. 1(b) and (d)). Conversely all groups given TP or AN had a decreased lipid content in liver cells; this was most pronounced in groups 3 and 5 (Fig. 1(f)). 


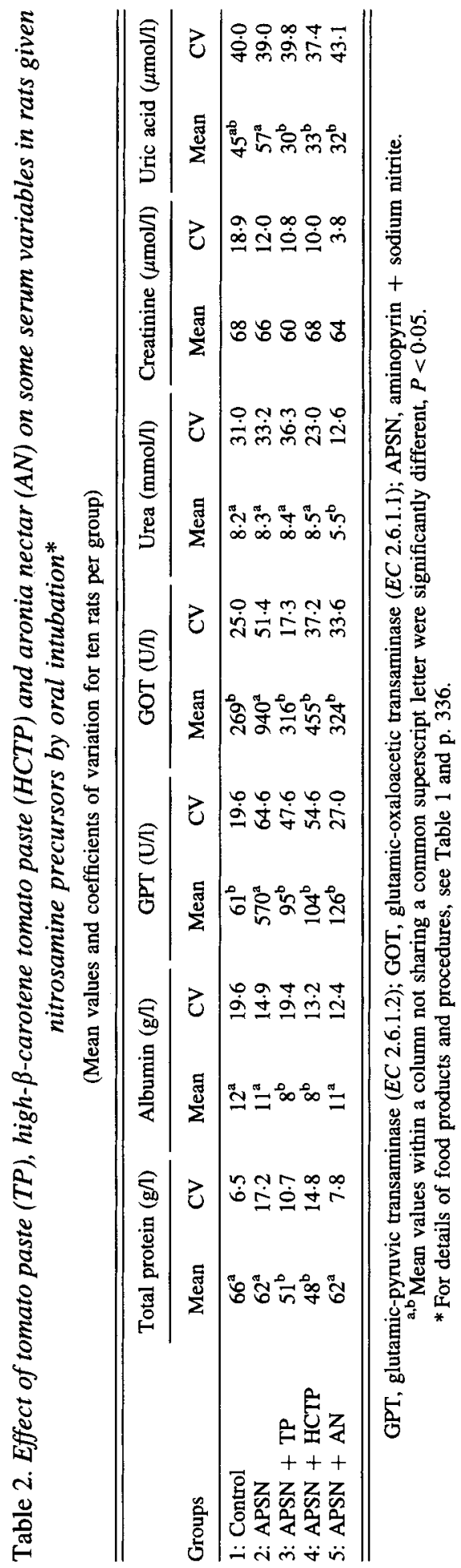


Table 3. Effect of tomato paste (TP), high-carotene tomato paste (HCTP) and aronia nectar (AN) on some haematological variables in rats given nitrosamine precursors by oral intubation*

(Mean values and coefficients of variation for ten rats per group)

\begin{tabular}{|c|c|c|c|c|c|c|c|c|}
\hline \multirow[b]{2}{*}{ Groups } & \multicolumn{2}{|c|}{$\mathrm{Hb}(\mathrm{g} / \mathrm{l})$} & \multicolumn{2}{|c|}{$\operatorname{Er}\left(\times 10^{12} n\right)$} & \multicolumn{2}{|c|}{$\begin{array}{l}\text { Leucocytes } \\
\left(\times 10^{9} / 1\right)\end{array}$} & \multicolumn{2}{|c|}{$\operatorname{ESR}(\mathrm{mm} / \mathrm{h})$} \\
\hline & Mean & $\mathrm{CV}$ & Mean & $\mathrm{CV}$ & Mean & $\mathrm{CV}$ & Mean & $\mathrm{CV}$ \\
\hline 1: Control & $139^{\mathrm{a}}$ & 9.7 & $6 \cdot 82^{\mathrm{a}}$ & $15 \cdot 4$ & $5 \cdot 4^{a}$ & $20 \cdot 2$ & $1 \cdot 3$ & 38.7 \\
\hline 2: APSN & $128^{\mathrm{ab}}$ & $8 \cdot 3$ & $5 \cdot 82^{\mathrm{ab}}$ & $18 \cdot 8$ & $3 \cdot 1^{\mathrm{bc}}$ & 31.9 & 1.7 & 31.0 \\
\hline 3: APSN + TP & $123^{\mathrm{ab}}$ & 5.5 & $5 \cdot 20^{\mathrm{b}}$ & $13 \cdot 8$ & $4 \cdot 0^{\mathrm{bc}}$ & $10 \cdot 5$ & $1 \cdot 3$ & $38 \cdot 7$ \\
\hline 4: APSN + HCTP & $113^{b}$ & 9.4 & $4.64^{b}$ & 7.0 & $3 \cdot 0^{\mathrm{c}}$ & 9.9 & 1.5 & $36 \cdot 5$ \\
\hline 5: APSN + AN & $140^{a}$ & 23.8 & $6 \cdot 80^{a}$ & $27 \cdot 0$ & $4 \cdot 7^{\mathrm{ab}}$ & 29.6 & 1.5 & $36 \cdot 5$ \\
\hline
\end{tabular}

$\mathrm{Hb}$, haemoglobin; Er, erythrocytes; ESR, erythrocyte sedimentation rate; APSN, aminopyrin + sodium nitrite. a,b,c Mean values within a column not sharing a common superseript letter were significantly different, $P<0.05$.

* For details of food products and procedures, see Table 1 and p. 336.

Table 4. Influence of tomato paste (TP), high- $\beta$-carotene tomato paste (HCTP) and aronia nectar (AN) on differential blood count of rats given nitrosamine precursors by oral intubation*

(Mean values for ten rats per group)

\begin{tabular}{lcccc}
\hline \hline Groups & $\mathrm{Ne}$ & Eo & Mo & Ly \\
\hline 1: Control & 0.34 & 0.02 & 0.04 & 0.61 \\
2: APSN & 0.44 & 0.02 & 0.02 & 0.53 \\
3: APSN + TP & 0.42 & 0.03 & 0.04 & 0.53 \\
4: APSN + HCTP & 0.46 & 0.02 & 0.03 & 0.50 \\
5: APSN + AN & 0.43 & 0.04 & 0.04 & 0.50 \\
\hline \hline
\end{tabular}

Ne, neutrophils; Eo, eosinophils; Mo, monocytes; Ly, lymphocytes; APSN, aminopyrin + sodium nitrite.

* For details of food products and procedures, see Table 1 and p. 336.

\section{DISCUSSION}

These results have established an inhibitory effect of the three food products on $\mathrm{N}$ nitrosamine production. TP exerted a positive effect on serum total protein and albumin content. It also sharply decreased GOT and GPT values which are the most important indices related to liver damage. Similar results were reported by Rubenchick et al. (1985) in experiments with apple pectin alone or enriched with ascorbic acid, as well as with drugs made from plantain (plantastin) and lime blossom (tiliaflan).

Neither of the TP diets affected serum urea or creatinine content but both significantly reduced the uric acid content.

In comparison with the two TP products AN showed a different pattern as far as serum variables are concerned. No changes were found in total protein or albumin content. Liver enzymes showed the same positive effect as for the two TP diets. AN exerted the strongest effect on the urea value which was reduced by $34 \%$. This demonstrates improved kidney function which is also evident when the urea value is compared with the control. With respect to haematological indices the inhibitory effect of $\mathrm{AN}$ was similar to that of both $\mathrm{TP}$ products. 
(a)
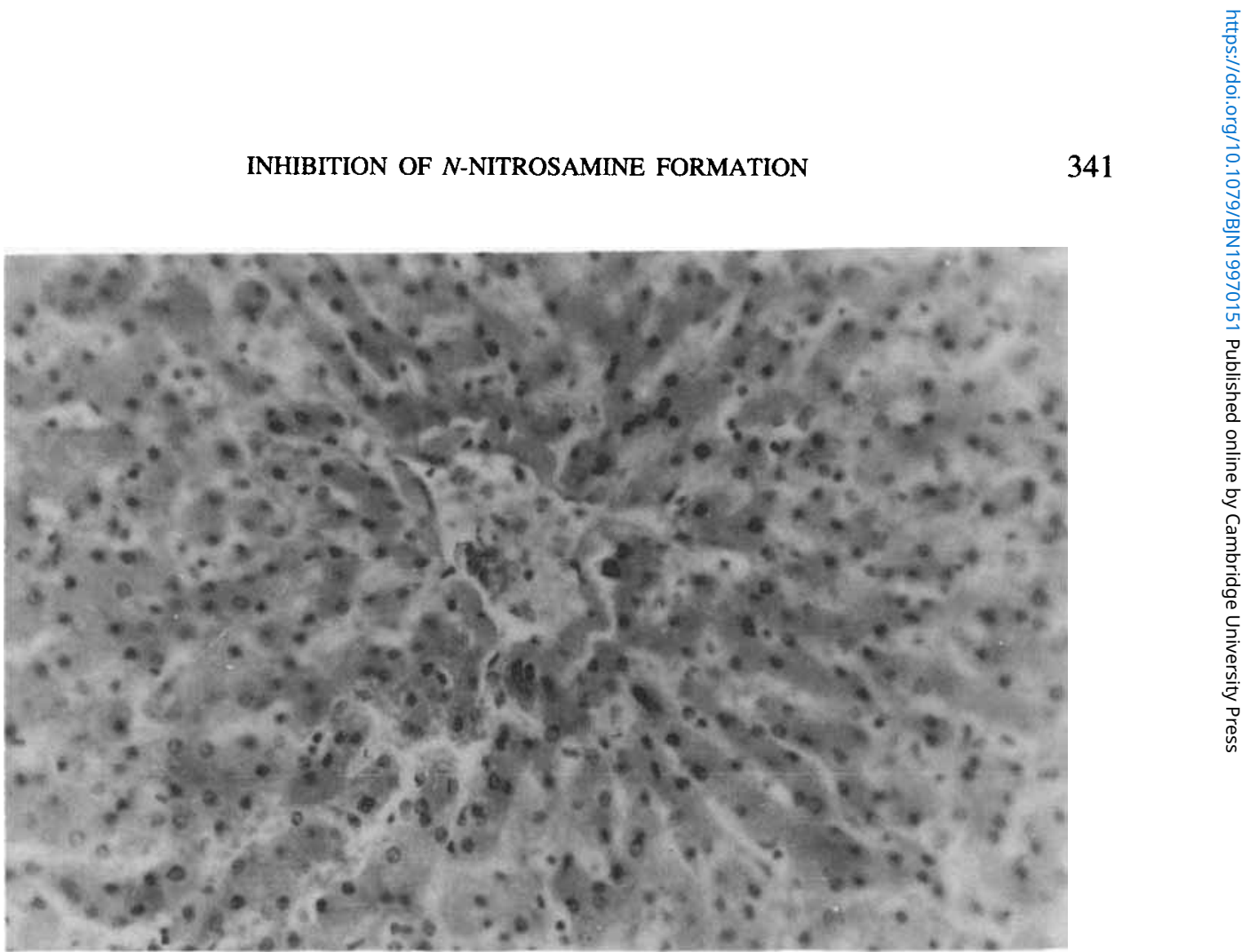

(b)

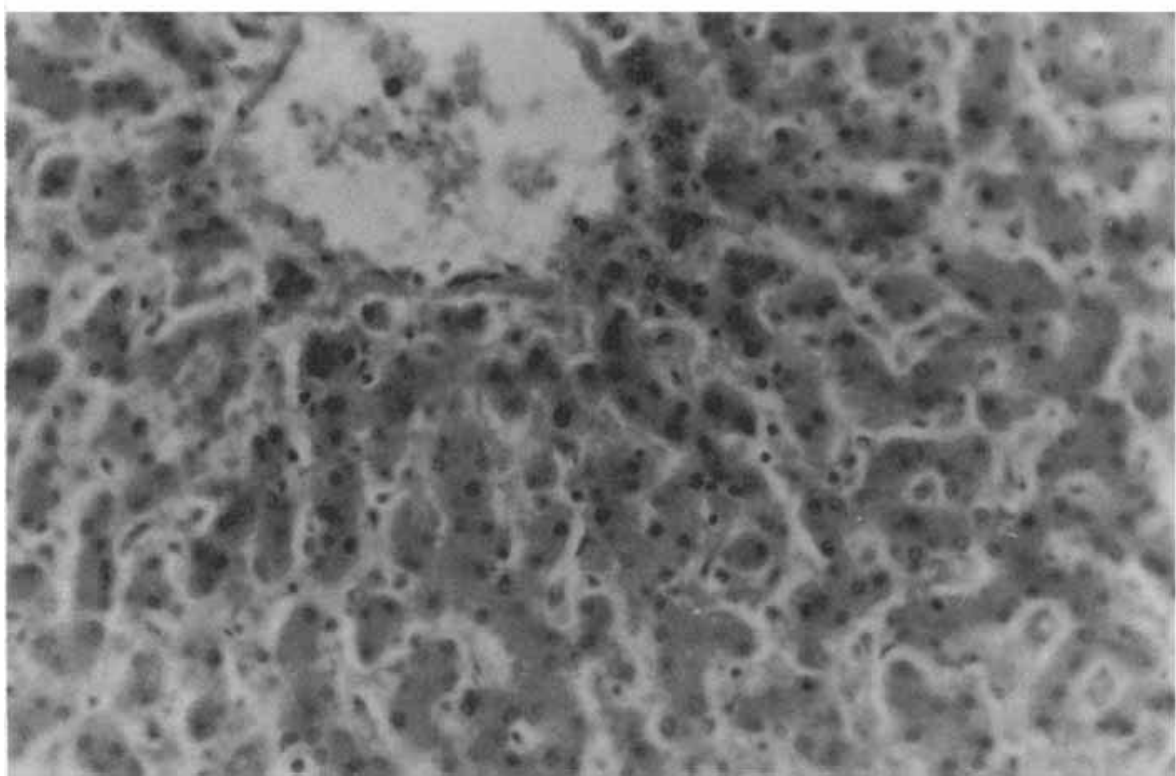

Fig. 1. Photomicrographs of liver samples taken from rats given nitrosamine precursors by oral intubation for $3 \mathrm{~d}$, either alone or together with tomato paste or aronia nectar (fruit juice + pulp of black chokeberry (Aronia melarocarpa Elliot)). Samples were prepared in paraffin wax, stained with haematoxylin and eosin and studied for structural change by light microscopy (a, c and e) or prepared by cryostatic segmentation and stained with Sudan III-H for total lipids (b, d and f). (a) Normal hepatic structure from an untreated animal (magnified $10 \times 40$ ). (b) Normal lipid inclusion in hepatocytes from an untreated animal (magnified $10 \times 40$ ). (c) Severely dilated vena centralis and dystrophic changes in the hepatic cells resulting from ingestion of nitrosamine precursors (magnified $10 \times 25$ ). (d) Severely increased lipid inclusion in hepatocytes resulting from ingestion of nitrosamine precursors (magnified $10 \times 40$ ). (e) Hepatic structure preserved in animals receiving tomato paste with nitrosamine precursors (magnified $10 \times 40$ ). (f) Almost normal lipid inclusion in hepatocytes of animals given aronia nectar with nitrosamine precursors (magnified $10 \times 40$ ). 
(c)

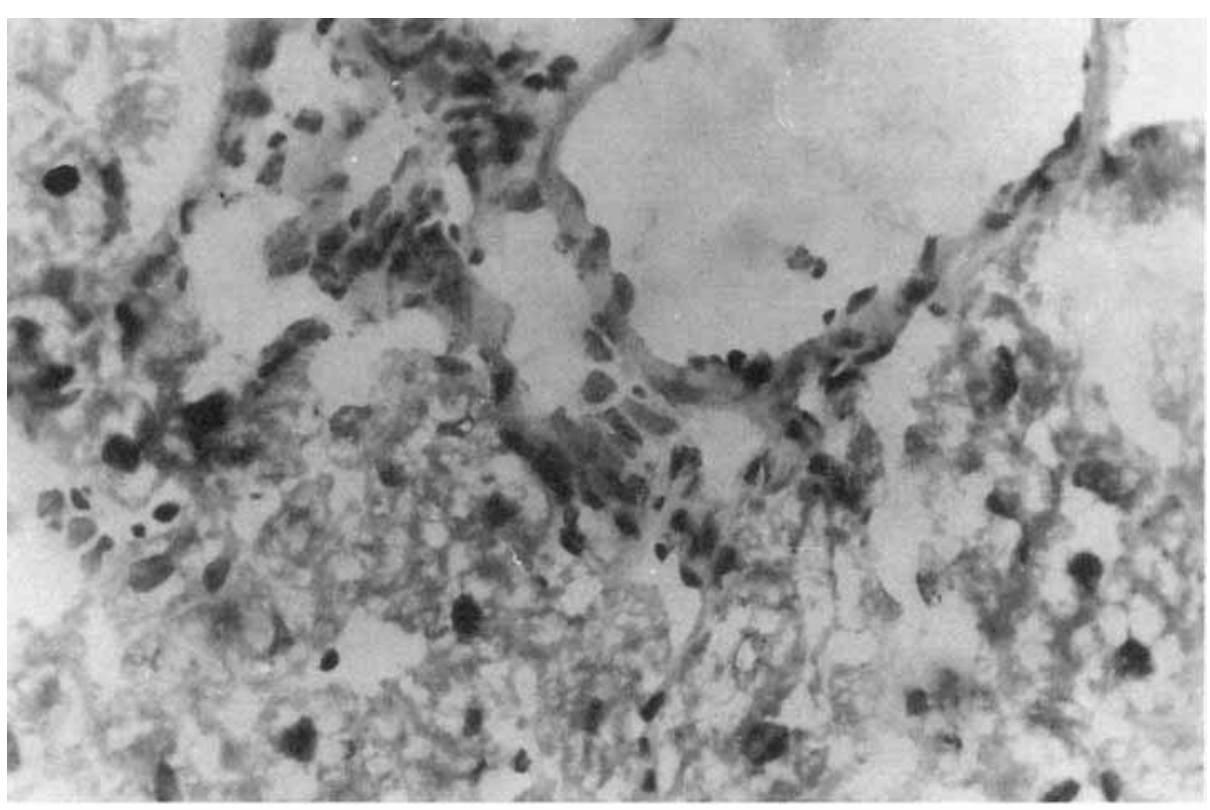

(d)

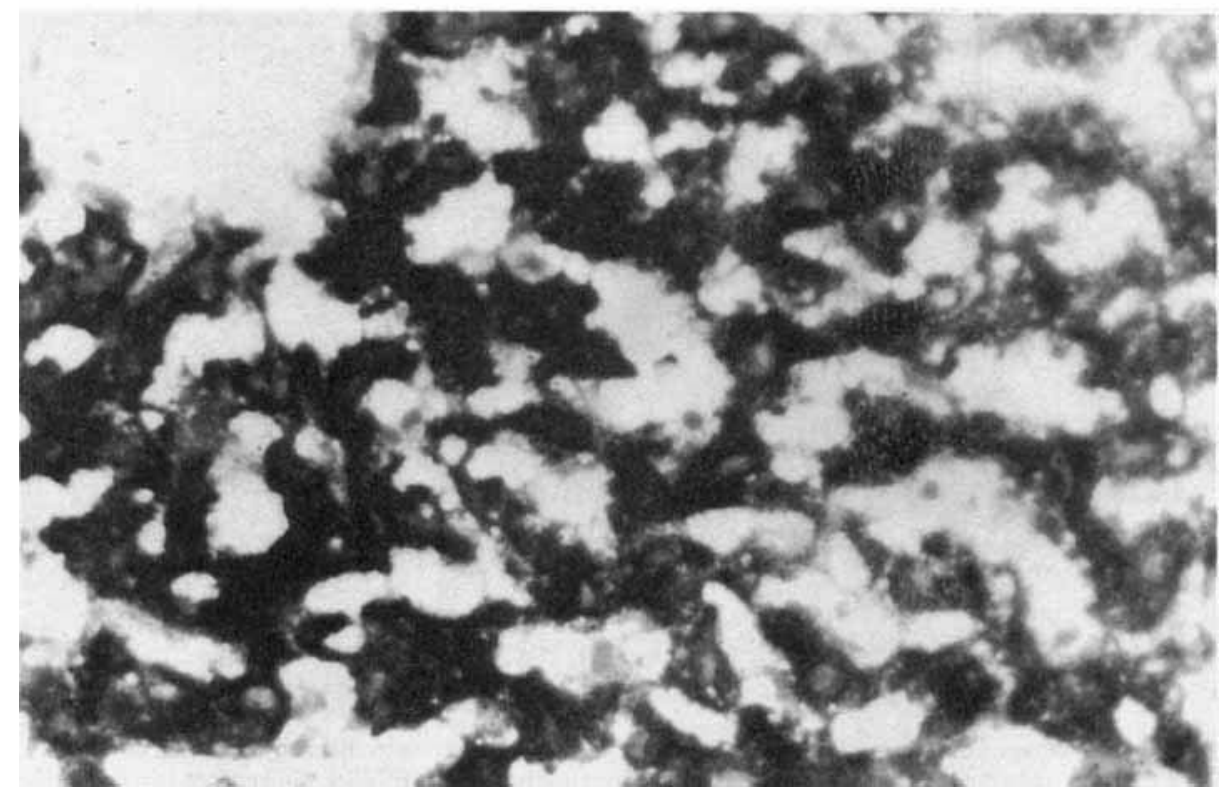

For legend, see p. 341. 
(e)

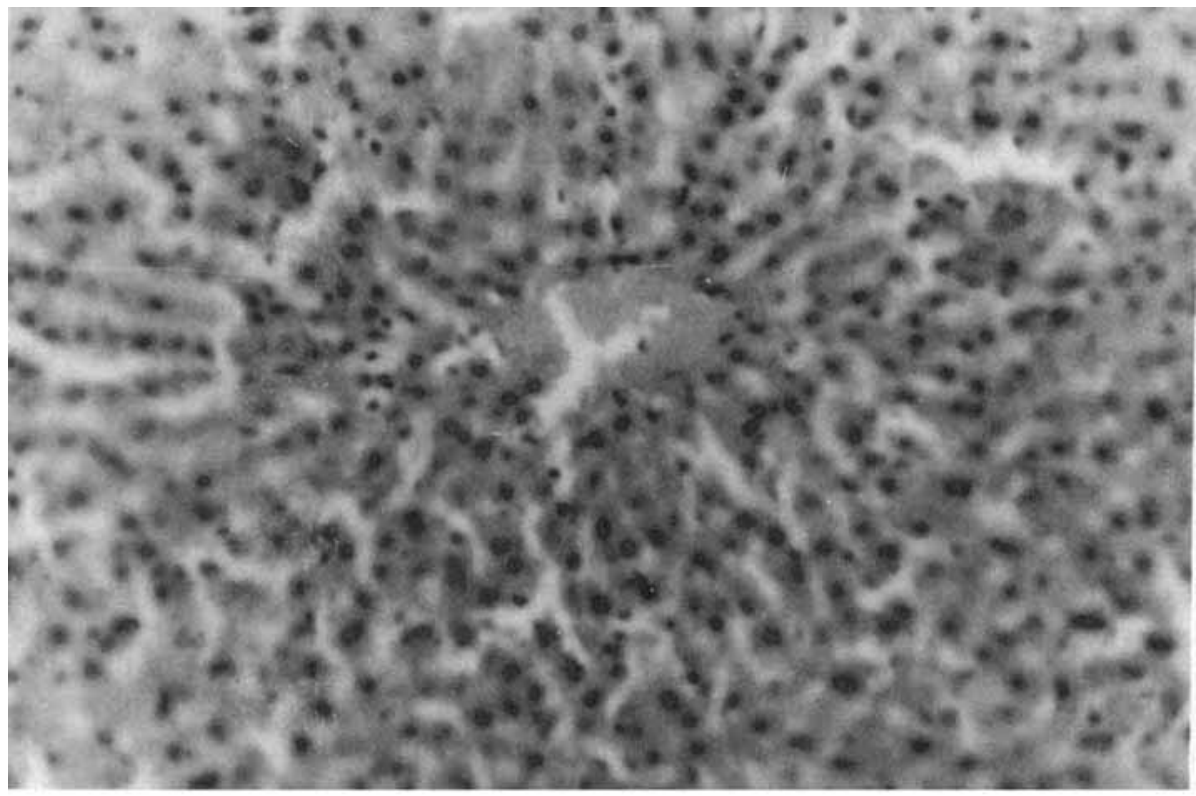

(f)

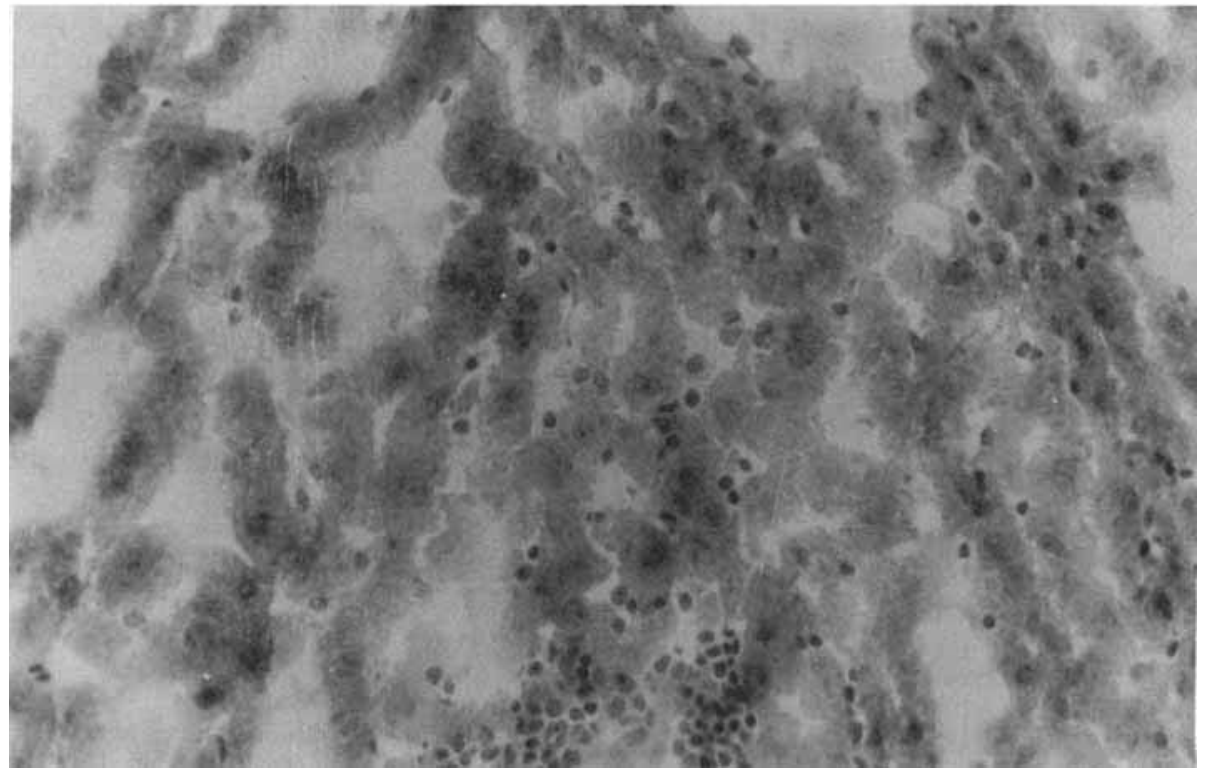

For legend, see p. 341. 
The histological and histochemical investigations of liver confirmed an inhibitory effect on nitrosamine formation of the food products used. Animals treated with APSN (group 2) showed dystrophic changes in liver that have been described by many authors (Rubenchick, 1979; Donchev \& Petrova, 1982; Rubenchick et al. 1983; Lin \& Ho, 1992; Tziganenko, 1993). These include centrolobular necrosis, intense exangia, hepatocytes showing an increased oxyphilic activity in the cytoplasm, and pyknotic nuclei in many cells. There were also enlarged cells with large nuclei and frequently with two nuclei (compare Fig. 1(a) and (c)). Addition of TP or AN to the diet resulted in a considerable protection of liver structure. Very few dystrophic changes were noticed, there was no centrolobular necrosis, nor were there any pyknotic nuclei or enlarged cells. These findings show the protective effect of the three food products in relation to liver structure; this was particularly evident in the diet containing TP (Fig. 1(e)).

A large quantity of lipid in hepatocytes causing adipose degeneration was found in animals of group 2 (compare Fig. 1(b) and (d)), while a considerable reduction in lipid content of liver cells was found with the rats of groups 3,4 , and 5 . This is further evidence of the inhibitory effect of the food products employed, and was most pronounced in the animals given AN (Fig. 1(f)).

The positive histological and histochemical profiles in the rats fed with the three food products correlated with the levels of serum GOT and GPT. There are a number of factors in these food products which may afford this protection against the harmful effects of nitrosamines. First, they may have changed the $\mathrm{pH}$ of the digestive tract; it has been shown that a $\mathrm{pH}$ of $3.3-4.8$ of the food product or the reaction mixture is likely to inhibit nitrosamine production (Rubenchik, 1979, 1990). Second, the AI, an indicator of the relative concentrations of ascorbate and nitrate in vegetable foods, may be one reason for the protective effects observed. A high AI, together with a high tannin content, is believed to be of benefit in preventing nitrosamine production (Petrova, 1987; Hristov et al. 1988; Mitov et al. 1990; Rooma \& Kann, 1993; Seidemann, 1993a,b). In the experiments described here, the beneficial effects of AN seem to be due to the high AI of this fruit. It is interesting to note therefore that this treatment appeared to be particularly effective in reducing plasma urea concentration. The effect of TP may be due to its high content of lycopene. In the case of the third food product, HCTP, it is the high $\beta$-carotene content that is the most important factor. All four of these factors appear to be important in the protection against the carcinogenic effects of nitrosamines.

We express our thanks to the team of the Laboratory of Histology, the team of the Department of Pharmacology and the Clinical Laboratory at the Higher Medical Institute, Plovdiv; to the chemists of the Laboratory of Quality and Professor H. Manuelyan, Head of the same laboratory, at the 'Maritsa' Institute and to engineer Hr Matev, Head of the Food Products Department, at the 'Maritsa' Institute.

\section{REFERENCES}

Boyadjiev, V. \& Markova, M. (1987). Applied Nutrition, 2nd ed., pp. 197-198. Sofia: Meditzina i Fizkultura. Council of Ministers (1981). Bulgarian State Standard no. 5162-81. Nectars. Sofia.

Council of Ministers (1985). Bulgarian State Standard no. 508-85. Tomato Concentrates. Sofia.

Donchev, N. \& Petrova, S. (1982). Pathomorphological changes in rat liver under the combined effect of dodin pesticide and sodium nitrite. Hygiene and Public Health 6, 558-564.

Holmes, A. W. (1971). Nitrosamine Research at BFMTRA Leatherhead Food Research Association. Layman's Guide no. 12. Leatherhead: Food Research Association.

Hristov, L., Ivanov, A., Koserkov, A. \& Nachevski, V. (1988). The Small Fruit Crops in Our Garden. Sofia: Zemizdat. 
Kamm, J. S., Dashman, T., Conney, A. H. \& Burn, J. K. (1975). Effect of ascorbic acid on aminonitrite toxicity. Annals of the New York Academy of Sciences 258, 1969-1974.

Lathia, D., Braash, A. \& Theissen, U. (1988). Inhibitory effect of vitamin C and $\mathrm{E}$ on in vitro formation of $N$ nitrosamines under physiological conditions. Frontiers in Gastrointestinal Research 14, 151-156.

Lin, J. K. \& Ho, I. S. (1992). Hepatotoxicity and hepatocarcinogenicity in rats fed squid with or without exogenous nitrate. Food and Chemical Toxicology 30, 695-702.

Mergens, W. J. (1992). Tocopherol: natural phenolic inhibitor of nitrosation. Phenolic Compounds in Foods and Their Effects on Health 2, 350-366.

Mitov, P., Angelov, T., Dimov, N., Pepelyankov, G. \& Dyakov, D. (1990). Fruit Growing. Sofia: Zemizdat.

Mitrov, G. \& Chemozemski, J. (1985). Nutrition and Cancer, 2nd ed., pp. 109-111. Sofia: Medicine and Physical Culture.

National Agro-Industrial Union (1985). Technological Instructions for the Food Processing and Canning Industry, vol. 6. Nectars. Sofia: National Agro-Industrial Union/Bulgarplod.

Petrova, V. R. (1987). Wild Fruits and Berries, 2nd ed., p. 96. Moscow: Forest Industry.

Rooma, M. Y. \& Kann, E. M. (1993). The ascorbic index as an indicator of the content of ascorbic acid and nitrate in the plant products. Voprosy Pitaniia 4, 54-56.

Rubenchick, B. L. (1977). Effect of food factors on the endogenous synthesis of carcinogenic nitrosocompounds. Voprosy Pitaniia 3, 168-175.

Rubenchick, B. L. (1979). Nutrition, Carcinogens and Cancer, 2nd ed., pp. 157-166. Kiev: Naukova Dumka.

Rubenchick, B. L. (1990). Formation of Carcinogenic Substances From Nitrogen Compounds. Kiev: Naukova Dumka.

Rubenchick, B. L., Karpilovskaya, E. D., Tiktin, L. A., Gorbany, G. P., Pliss, M. B., Zakharenko, L. N., Goulich, M. P., Maksiutina, N. P., Ivanissenko, V. G. \& Gritzenko, E. N. (1985). Food inhibitors of formation of carcinogenic nitrosocompounds. Voprosy Pitaniia 1, 48-51.

Rubenchick, B. L., Kostjukovskii, Y. I. \& Melamed, D. B. (1983). Protection of Food Products From Contamination with Carcinogenic Substances, 3rd ed., p. 18. Kiev: Zdorovia.

Seidemann, J. (1993a). Chokeberries - a fruit little known till now. Denthe-lebensmittel-rundschau 89, $149-151$.

Seidemann, J. (1993b). Aronia fruits - lant anatomy, fruit components and food use. Lebensmittekontrole 8 , 46-47.

Shahidi, F. \& Pegg, R. B. (1993). Nitrite free meat curing systems and the $N$-nitrosamine problem. In Food and Cancer Prevention, pp. 82-86 [K. W. Waldron, I. T. Johnson and G. R. Fenwick, editors]. Cambridge: Royal Society of Chemistry.

Tannenbaum, S. R. (1989). Preventive action of vitamin C on nitrosamine formation. International Journal of Vitamin and Nutrition Research 30, Suppl., 109-113.

Tannenbaum, S. R., Wishnok, J. S. \& Leaf, C. D. (1991). Inhibition of nitrosamine formation by ascorbic acid. American Journal of Clinical Nutrition 53, 2475-2505.

Technicon Instruments Corporation (1985). Technicon RA-1000 TM System. Tarrytown, NY: Technicon Instruments Corporation.

Todorov, Y. (1962). Clinical and Laboratory Studies in Childhood. Sofia: Medicine and Physical Culture.

Tziganenko, O. I., Hmelnitzkii, G. A., Bokor, A., Lapchenko, B. S., Emchenko, N. L., Rimar-Shcherbina, N. B., Goulich, M. P. \& Gil, N. A. (1993). Methodical approach in the determination of nitrate toxicity levels in big laboratory animals. Gigiena $i$ Sanitaria 4, 30-33.

Zhukova, G. F., Maslova, E. A. \& Vasilevskaya, L. S. (1990). Influence of certain food products on endogenous formation of $N$-nitrosamines in rats. Voprosy Pitaniia 3, 43-47.

Zhukova, G. F., Pozniakovslii, V. M., Egorchenkova, Z. A., Maslova, E. A., Panin, A. V. \& Spirichev, V. B. (1989). Influence of thiamine, riboflavin, nicotinamide and ascorbic acid on nitrosamine formation in meat products. Voprosy Pitaniia 6, 58-61. 